\section{Dementia-friendly dentistry}

To be a dementia-friendly practice you need to be:

- Accepting of the patient's behaviour, even when it seems a little confused, critical, aggressive or defensive. Keep careful records of conversations and most importantly give the patient all important information in a written format

- Aware that for many dementia sufferers, time is an issue and so delays and being kept waiting trigger their symptoms
- Helpful and patient - stress increases confusion as too does a noisy environment; whenever possible find a quiet place to talk

- Patient - don't rush them, give them the time they need to process information (MCA Principle 2 - Patients should be given the necessary support to enable them to protect themselves)

- Aware that any changes in the practices will be problematic for dementia sufferers - be supportive

- Prepared with 'in case of emergencies' contact details should you need to make a 'best interests' disclosure to the family about your concerns.

Remember that this condition is a physical illness. So that dental carers can accommodate the patients' need for all communication to be clear, they should imply that the question is being put for the first time, even when the same question has already been asked several times.

CMIPD, RDN, Dip.DPM, Training Consultant

\title{
EVENT REPORT
}

\section{'A heart-warming and truly humbling experience'}

Associate Dentist and Clinical Teacher A. J. Holder reports on being part of Team Special Smiles at the Special Olympics GB National Summer Games held in Sheffield.

I n August 2017 Sheffield played host to the Special Olympics GB National Summer Games, the largest multi-sports event ever held in Britain for athletes with intellectual disabilities.

Special Olympics was founded in 1968 by Eunice Kennedy Shriver, sister of President John F. Kennedy, and its aim is to transform lives through the joy of sport. Today this vision reaches out to over 4 million athletes in more than 170 countries worldwide.

Special Olympics GB was founded in 1978, and the National Summer Games held in Sheffield in August 2017 was the 10 th event of its kind. Over 2,600 athletes from across Britain attended the competition, along with representatives from Ireland and Australia. In addition to the athletes, there were over 1,000 volunteers and officials, including members of the Special Olympics Healthy Athletes Programme, which consisted of volunteers from a number of different health specialties, including the dentistry subsection, Team Special Smiles. The Special Olympics Healthy Athletes Programme aims to deliver friendly, fun, and accessible health assessments to the athletes participating at the games, and data collected from the screening process is submitted to the world's largest database on the health of people with intellectual disabilities.

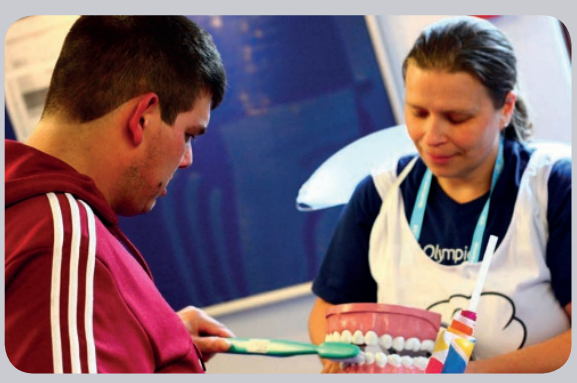

Fig. 1 The tooth fairy providing oral hygiene instruction

\section{Team Special Smiles for the National} Summer Games was organised by Nicole Dunning, Consultant in Community and Special Care Dentistry, and Adam Holder, DCT2 in Community and Special Care Dentistry. Over 40 dental volunteers participated in Team Special Smiles during the week, with volunteer experience ranging from undergraduate students through to consultants. All volunteers felt the Special Olympics was a fantastic experience, which was fun, worthwhile and rewarding. As part of Team Special Smiles, volunteers participated in dental screening and oral health promotion (Figs 1-2), as well as attending the Special Olympics opening ceremony, and the wide range of sports competitions on offer. Everyone involved agreed Special Olympics embodied what sport is truly about - fun, fitness, team work, and inclusion, and all the volunteers felt honoured to be part of a wonderful occasion.

Following completion of the dental screening

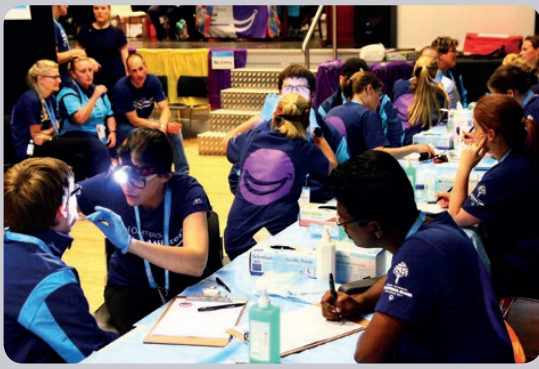

Fig. 2 The Special Olympic athletes dental screening process in action

and oral health promotion, each athlete was provided with a summary sheet detailing our findings, a suggested course of action for their care, and a participation bag containing toothbrushes and toothpaste. The feedback we received from the athletes, coaches, family members, and other volunteers was very positive and it was a pleasure to be involved in such an event. In total as part of Team Special Smiles, we screened over 700 athletes across the equivalent of $3 \frac{1}{2}$ working days, and we also managed a small number of urgent cases identified during the screening process. Overall the Special Olympics GB National Summer Games was a heart-warming and truly humbling experience, and was something I am sure will live long in the memory of everyone involved.

For further information on the Special Olympics, including how to get involved in future events, please see www.specialolympics.org. 